\title{
Does It Pay to Move from Welfare to Work?
}

\section{Sheldon Danziger Colleen M. Heflin Mary E. Corcoran Elizabeth Oltmans Hui-Chen Wang}

\begin{abstract}
The 1996 Personal Responsibility and Work Opportunity Reconciliation Act requires welfare recipients to look for work and has made it more difficult for nonworking recipients to remain on the welfare rolls. In addition, the economic boom of the 1990s and changes in federal and state policies have raised the net income gain associated with moving from welfare to work. This paper analyzes data from a panel survey of single mothers, all of whom received welfare in February 1997. In 1999, those who left welfare and were working had a higher household income and lower poverty rate, experienced a similar level of material hardship, engaged in fewer activities to make ends meet, and had lower expectations of experiencing hardship in the near future than did nonworking welfare recipients. Estimations of fixed-effect regressions of income that control for both observable and unobservable time-invariant characteristics show that monthly net income increases by $\$ 2.63$ for every additional hour of work effort. About 60 percent of the observed monthly income difference between wage-reliant and welfare-reliant mothers can be attributed to differences in their work effort. Thus, after welfare reform, it does pay to move from welfare to work. (C) 2002 by the Association for Public Policy Analysis and Management.
\end{abstract}

\section{INTRODUCTION}

Prior to the Personal Responsibility and Work Opportunity Reconciliation Act of 1996 (PRWORA), conventional wisdom held that it did not pay to move from welfare to work. Economists emphasized the high marginal tax rate implicit in the Aid to Families with Dependent Children Program (AFDC). According to Rebecca Blank, "When a woman goes to work, her benefits decline rapidly as her earnings increase. This means that her income gains from employment are limited, since she loses close to a dollar in benefits for every dollar she gains from work" (1997, p. 146). Sociologists emphasized the difficulties in coping strategies caused by the transition from welfare to work. Kathryn Edin and Laura Lein concluded that "mothers generally found it more difficult to make ends meet when they worked than when they collected welfare" (1996, p. 254).

This paper reports an analysis of data gathered from a panel study of single mothers who received cash welfare in an urban Michigan county in February 1997. It addresses the question: Does it pay to move from welfare to work in the after-

Manuscript received received April 2000; review completed June 2000; revision completed August 2001; 2nd review completed February 2002; 2nd revision completed April 2002; accepted April 2002..

Journal of Policy Analysis and Management, Vol. 21, No. 4, 671-692 (2002)

(C) 2002 by the Association for Public Policy Analysis and Management

Published by Wiley Periodicals, Inc. Published online in Wiley InterScience (www.interscience.wiley.com) DOI: $10.1002 /$ pam.10080 
math of the 1996 welfare reform? The key finding is that by the late 1990s, single mothers who had been welfare recipients were, on average, financially better off working or combining work and welfare than remaining as nonworking welfare recipients. Mothers who were working in Fall 1999, about 34 months after the sample was drawn, had a higher household income and lower poverty rate, experienced similar levels of material hardship, engaged in fewer activities to make ends meet, and had lower expectations of experiencing hardship in the near future than did nonworking welfare recipients. Nonetheless, almost half of the work-reliant respondents were poor in 1998, about half experienced at least two material hardships in the year before the Fall 1999 interview, and more than one-third had no medical insurance.

\section{ECONOMIC AND PUBLIC POLICY CHANGES IN THE 1990s}

The relative financial benefits of moving from welfare to work changed dramatically over the course of the 1990s. First, several policy changes were implemented that affected the net income of single mothers. PRWORA replaced the entitlement program, Aid to Families with Dependent Children (AFDC), with the Temporary Assistance for Needy Families (TANF) program. TANF reduces the likelihood that a single mother can "choose" to remain a welfare recipient, because even if she finds that the economic benefits of working do not exceed its costs, cash assistance is conditional on the performance of work-related activities or community service. Work requirements and the fact that states must sanction recipients who do not comply with requirements reduce a nonworking recipient's expected welfare income. In addition, the imposition of a 60-month lifetime limit on benefit receipt increased pressure to enter the labor force.

In response to PRWORA's granting them more autonomy, 36 states have increased "earnings disregards," which allow recipients to have some earnings that do not directly offset welfare benefits (Acs et al., 1998; Gallagher et al., 1998; Pavetti, 2002). Most states have also increased spending on child care for recipients and former recipients. Taken together, these changes require more recipients to look for work, make it more difficult for nonworking recipients to receive cash assistance, and make it easier for them to receive cash and child care assistance if they have low earnings.

Policy changes outside welfare have also increased the benefits of moving from welfare to work. The minimum wage increased from $\$ 4.25$ to $\$ 5.15$ in 1997 , and a major expansion of the earned income tax credit (EITC) increased the maximum credit from $\$ 950$ in 1990 to $\$ 2272$ in 1998 for a working single mother with one child, and to $\$ 3756$ for those with two or more children.

Prior to reform, the move from welfare to work typically left both the mother and children uninsured because most jobs recipients take do not provide employer-subsidized insurance. Transitional Medicaid covers adults leaving TANF for a year. However, the State Child Health Insurance Program (CHIP) of 1997 and changes in Medicaid policy have expanded coverage, making jobs that do not provide health care coverage more attractive. States can now cover low-income working parents who have no recent connection to cash welfare and can establish Medicaid eligibility limits much higher than those in the past (Broaddus et al., 2002). By the end of the 1990s, leaving welfare for work was less likely to result in a mother and her children being uninsured.

The labor market in the late 1990s was much tighter than it had been for several decades, increasing the likelihood that recipients who must search for work will find jobs (Holzer and Stoll, 2001). In October 1991, the national unemployment rate for 
adult females was 5.9 percent; it had fallen to 3.6 percent by October 1999 (about the time of the interviews that gathered the data reported here).

Against this background of state and federal policy changes and a long economic boom, welfare caseloads fell dramatically after the mid-1990s. Some of this decline was due to welfare reform and the associated policy changes; some to the booming economy (Danziger, 1999). No attempt has been made to account for the relative contribution of the various economic and policy changes to the finding that current and former welfare recipients who are working are financially better off than nonworking welfare recipients. To do so requires a behavioral model of labor supply and welfare participation decisions that is beyond the scope of this paper. Rather, we document how the economic circumstances of former and current recipients who are working compare to those of nonworking welfare recipients.

\section{RELATED STUDIES}

Results discussed here are the first to be based on post-welfare reform panel data that include detailed information on both "welfare leavers" and "welfare stayers." Related studies analyze economic well-being among work-reliant and welfare-reliant single mothers with data gathered before welfare reform; other studies evaluate the effectiveness of policy changes in the late 1990s in encouraging single mothers to move from welfare to work; others assess the well-being of welfare leavers.

These studies do not directly address whether, in the aftermath of the 1996 reform, it pays to move from welfare to work. Addressing this issue requires panel data on the subsequent income and experience of material hardship of a sample that includes both welfare leavers and welfare stayers. When we compare the well-being of women in our panel, we distinguish between workers who have left welfare, those who are combining work and welfare, and those who are nonworking welfare stayers.

Most studies of welfare leavers have no information on welfare stayers, and tend to include limited data on the income sources and material hardships of leavers. They answer the question, "What is the financial well-being of all recipients who have left welfare, whether or not they are working?"

\section{Pre-Welfare Reform Studies}

The pre-welfare reform literature provides mixed evidence on whether or not it does pay to leave welfare for work. Edin and Lein $(1996,1997)$ conclude that the economic benefits of working are outweighed by the economic costs associated with work. Between 1988 and 1992, they interviewed 165 single mothers who were working but not currently receiving welfare (whom they call wage reliant) and 214 single mothers who were currently receiving welfare, some of whom were working in the formal or informal labor market (welfare reliant). The women were selected using "snowball" survey techniques in four urban areas and were asked detailed questions about income sources, consumption patterns, and experiences of material hardship. Working mothers did have a higher average income than welfare mothers. However, Edin and Lein concluded that the former fared worse economically than the latter because, in most cases, the costs of work eroded this income advantage. In addition, 42 percent of working mothers lacked health insurance, whereas Medicaid covered all welfare mothers.

In contrast, analyses of nationally representative samples find that women who work are financially better off than those who are welfare reliant. Bauman (2000), using the 1991 and 1992 panels of the Survey of Income and Program 


\section{4 / Does It Pay to Move from Welfare to Work?}

Participation (SIPP), finds that women who left welfare have a lower poverty rate and similar levels of material hardship than those who remain on welfare. Similarly, using the 1992 SIPP panel, Beverly (2000) finds that poor households with children who met current TANF work requirements reported lower levels of food insufficiency, eviction, and lack of phone service, and an overall higher income-to-needs ratio than those who did not work. She also finds that poor households who were employed reported more medical needs than those in nonworking households.

In addition to using data gathered before the implementation of TANF and the other policy changes of the late 1990s, these studies do not directly answer the question regarding the economic benefits of moving from welfare to work because their samples include many women who have not received welfare and who are likely to differ in important ways from welfare recipients.

\section{Evaluations of Policy Changes in the Late 1990s}

Conclusions from studies that evaluate the benefits of moving from welfare to work after welfare reform are mixed. Ellwood (2000) and Meyer and Rosenbaum (2000) find that policies implemented in the 1990s increased the financial benefits of moving from welfare to work. Less positive results are reported by Bavier (2001a), Cancian et al. (2002), and Wolfe (2002).

Ellwood (2000) describes a hypothetical scenario in which a nonworking welfare recipient taking a full-time job paying the minimum wage would have increased her net income by $\$ 2005$ (24 percent) in 1986 , but by $\$ 7119$ (95 percent) in 1996 . Meyer and Rosenbaum (2000) examine the effect of policy changes on the employment of single mothers over the 1984-1996 period using data from the Current Population Surveys. They document the increased returns to working that result from the expanded availability of federal and state earned income tax credits and the expansion of Medicaid eligibility.

Post-welfare reform, there is great variation among states in the incentive structure facing women moving from welfare to work. Wolfe's (2002) analysis of Wisconsin confirms that at low levels of earnings, marginal tax rates are now lower than they were before reform. However, marginal tax rates in Wisconsin now exceed 100 percent when earnings range between $\$ 12,000$ and $\$ 30,000$, more than they were before reform.

Bavier (2001a) uses SIPP data to compare employment rates and incomes associated with welfare exits and re-entries in the 1996-1997 period. He finds that the median leaver experienced a decline of about $\$ 50$ in household income in the exit month relative to the month before exit. In further analyses comparing pre- and post-welfare reform cohorts, Bavier (2001b) finds that recipients post-welfare reform were more likely to have earnings than recipients pre-welfare reform. However, once off the rolls, post-reform leavers were more likely than earlier leavers to experience economic difficulties.

Cancian et al. (2002) use administrative data from Wisconsin and find that more than half of women who left AFDC in 1995 and 1997 increased their earnings within one year of exiting welfare relative to their earnings while on welfare. Fewer than one-third of leavers, however, improved their total income relative to what it was before their welfare exit (as measured by the value of their post-tax earnings plus food stamps and cash assistance, but not including the income of other household members or other transfer income). Three years after exiting welfare, 59 percent of the 1995 leaver families remained poor. 
Thus, Bavier (2001a), Cancian et al. (2002), and Wolfe (2002) show only modest improvements, or slight declines, in financial well-being for those moving from welfare to work. However, these studies do not present comprehensive measures of the extent of changes in the financial well-being of women who make the transition from being nonworking welfare recipients to being working nonrecipients.

In this paper, data from the Women's Employment Study (WES) are analyzed. The data include comprehensive measures of income, experiences of material hardship, hardship-mediating activities, and expectations of future hardship. Using panel data, a fixed-effects model is estimated that controls for both measured observed and unobserved time-invariant characteristics of working leavers and nonworking stayers.

\section{DATA}

Respondents in the Women's Employment Study were systematically selected with equal probability from an ordered list of single mothers with children who received welfare benefits in an urban Michigan county in February 1997. Eligible respondents resided in this county, received cash assistance from Temporary Assistance to Needy Families (TANF), were U.S. citizens between age 18 and 54, and were either Caucasian or African-American. ${ }^{1}$ Interviews were conducted with the women in Fall 1997, Fall 1998, and Fall 1999. The response rate was 86 percent for the first wave $(n=753), 92$ percent for the second wave $(n=693)$, and 91 percent for the third wave $(n=632)$ of the panel study. The first two interviews lasted approximately one hour; the third, about 90 minutes. $^{2}$

The Fall 1999 interview, upon which the following discussion is based, occurred about 34 months after the sample was drawn. Respondents were asked to report, for the month before the interview, work hours, earnings, welfare receipt, income from a variety of sources, and work-related child-care and transportation expenses. Monthly income sources include own earnings, earnings of other household members, cash assistance from TANF, food stamps, Social Security and other pension and disability income, such as Supplemental Security Income (SSI), unemployment compensation, child support, cash contributions from friends and family outside the household, and any other sources of income not previously mentioned. They were also asked about total own earnings and total household income for calendar year 1998. (An appendix providing details on variable definitions and measurement issues is available from the authors upon request.)

Respondents were also asked about 10 kinds of material hardship-food problems, lack of health insurance (mother), unmet medical needs (mother), lack of health insurance (child), unmet medical needs (child), housing upkeep problems, utility cutoffs, evictions, experiences of homelessness, and disconnection of a telephone. These hardships are similar to those reported in Mayer and Jencks (1989) and Edin and Lein (1997, p. 113).

Respondents were asked about their subjective assessments of well-being ("How difficult is it to live on your income right now?") and whether they had engaged in any of the following activities to make ends meet in the six months before the interview-pawned or sold personal possessions; provided blood or plasma for cash;

\footnotetext{
${ }^{1}$ The sample frame included active single-parent with child cases and excluded child only and two-parent cases.

${ }^{2}$ Respondents interviewed at the first three waves represent 72 percent of the original sample, i.e., 0.86 x 0.92 x 0.91. A fourth interview was completed in Fall 2001 with a 91 percent response rate.
} 
sold or traded food stamps; engaged in illegal activity; and received food, shelter, or clothing from a charity in the previous 12 months.

Given the high response rate and the extensive survey instrument, these data are well-suited for testing the hypothesis that, in the post-welfare reform era, single mothers who move from welfare to work are financially better off than if they had remained nonworking welfare recipients. Michigan's welfare policies are quite similar to those of many other states. For example, women in Michigan who worked part-time at minimum wage jobs were at the median for monthly net income among 12 states that contained a large portion of the nation's population and about half of the 1998 caseload (Acs et al., 1998). While the study uses data only from Michigan, the policy and economic conditions in Michigan are broadly representative of the majority of the TANF caseload.

\section{RESULTS}

Respondents are classified into four mutually exclusive categories based on their work and welfare status in the month before the survey when current economic well-being is analyzed, and into five mutually exclusive work and welfare categories when well-being over a one-year period is analyzed.

\section{Monthly Income}

In Table 1, wage-reliant mothers are defined as those among the 632 respondents who reported earnings, but who, according to the state agency, received no cash assistance in the month prior to the Fall 1999 interview; they represent 54.7 percent of the sample $(\mathrm{n}=346) .^{3}$

Combiners are defined as women who both reported earnings and received cash assistance in the month before the interview; they represent 18.0 percent of the sample $(\mathrm{n}=114)$. This group is more common post-welfare reform than in the early 1990 s because of the increased earned income disregards. Welfare-reliant mothers are defined as those who reported no income from earnings in the month prior to the interview, but who are reported by the state agency as receiving TANF; they represent 13.8 percent of the Fall 1999 sample $(n=87)$. The remaining 13.4 percent $(n$ $=85$ ) of the sample includes women who were neither working nor receiving TANF benefits in Fall 1999. ${ }^{4}$

Thus, in Fall 1999, about three-quarters of all respondents were working (wagereliant plus combiners), and about one-third were receiving TANF (welfare-reliant plus combiners). There was a large movement from welfare to work over the study period, as all respondents received cash assistance in February 1997 and only about 40 percent worked at that time. At wave one, 21.4 percent were wage-reliant; at

\footnotetext{
${ }^{3}$ Some women told us that they received welfare income in the month prior to the survey; however, the welfare agency record says they did not receive assistance in that month. We classified them as wagereliant in Table 1, because the classification used in subsequent tables is based on the number of months of welfare receipt as reported in the agency records. We did include the welfare income they reported to us in our computation of monthly income.

${ }^{4}$ There were 23 women who received SSI benefits in Fall 1999. In our studies of the determinants of work (e.g., Danziger, 2001) we exclude them from analysis because they are not subject to the work requirements of the new welfare system. We include them here because our focus is on the financial well-being of all women in the sample. Our empirical results are not affected by their inclusion or exclusion as they represent only 3.6 percent of the sample.
} 


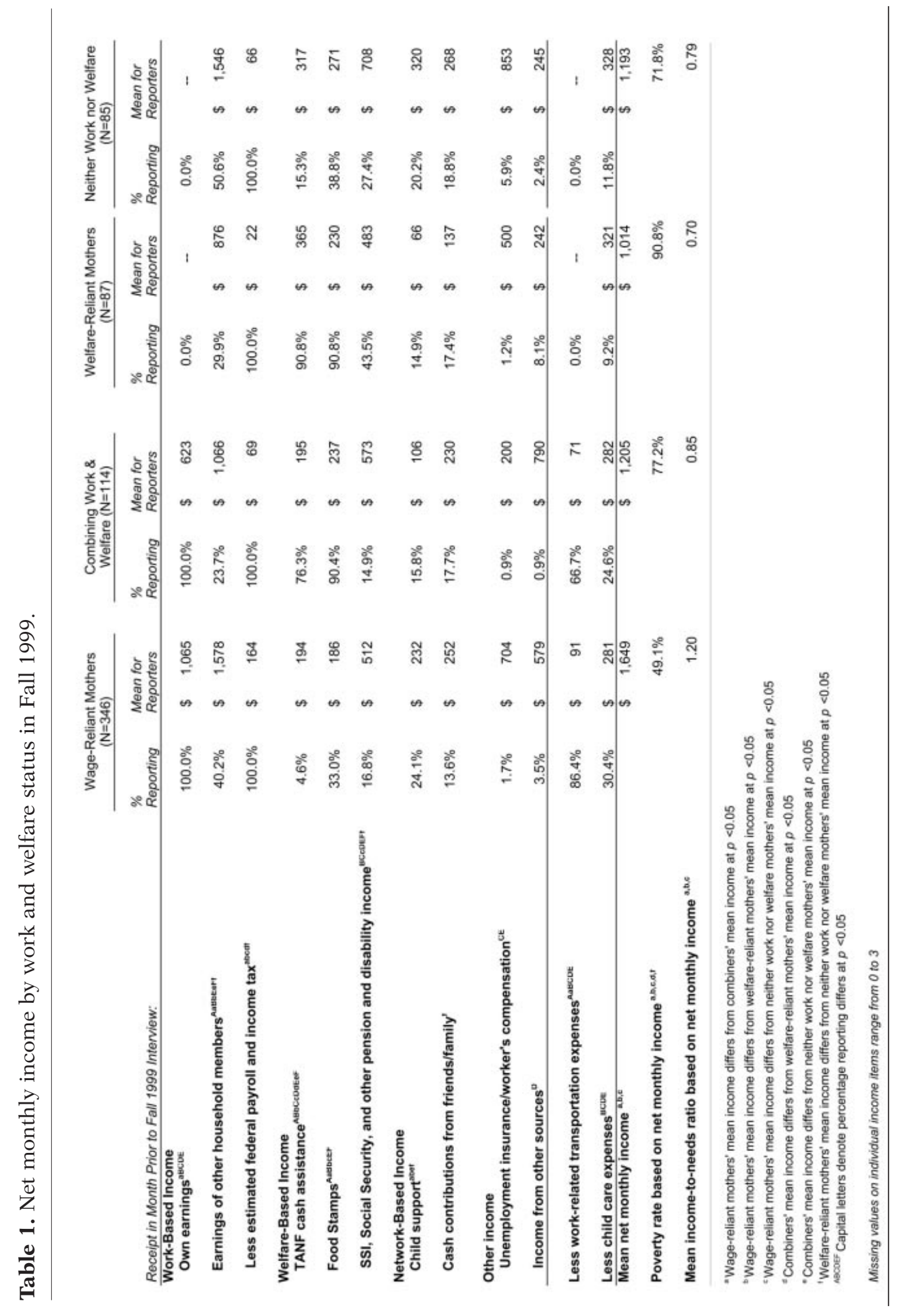


wave two, 43.7 percent; at wave 3, 54.7 percent. Respondents tended to move first from being welfare reliant to being combiners, and then to wage reliance. The percentage of the sample who were combiners fell from 43.1 to 27.6 to 18.0 percent between waves 1 and 3 .

Table 1 presents, for each of the four groups, the percentage of respondents who received income from each of the listed income sources or reported work-related expenses and the average value for recipients for each income source and for workrelated transportation and child-care expenses. ${ }^{5}$

Work-based Income. Work-based income is the sum of respondents' own earnings and the earnings of other household members, less the estimated value of federal income and payroll taxes. For monthly income, neither the value of the earned income tax credit (EITC) nor state income tax credits was imputed because they are almost always received as a lump sum after the year's tax forms have been filed. Analysis of annual income (below) includes the EITC and state of Michigan income taxes and credits. Taxes are imputed using the TAXSIM program of the National Bureau of Economic Research (Feenberg and Coutts, 1993).

By definition, all wage-reliant women and all combiners had earnings in the month prior to the interview, whereas welfare-reliant mothers and those neither working nor on welfare did not. Wage-reliant mothers earned more than did combiners, $\$ 1065$ vs. $\$ 623$, a differential that reflects both higher work hours and higher wage rates for wage-reliant women. Compared with women combining work and welfare, wagereliant mothers were more likely to work 35 or more hours per week (69 percent vs. 38 percent), and they earned a higher average hourly wage (\$7.83 vs. \$5.89).

Substantial numbers of respondents co-reside with another household member who had earnings in the month before the survey. About 40 percent of wage-reliant mothers, 24 percent of combiners, 30 percent of welfare-reliant mothers, and half of women neither working nor receiving welfare lived with an additional earner. These other earners, many of whom were husbands or cohabiting partners, earned on average substantially more than the respondents, the mean amounts ranging from $\$ 876$ to $\$ 1578$. Interestingly, the lowest mean for the four groups is that of other earners who reside with welfare-reliant mothers (although the mean for combiners is not significantly higher).

The third line of Table 1 subtracts estimated federal income and payroll taxes. Both respondents and other earners were assumed to have paid the 7.65 percent employee share of the payroll tax. Income taxes were estimated on total household income for married women, and on total household income less the income of others for women who are not married. (Lack of information precluded estimating income taxes for other earners; see the Appendix for further detail.) Taxes are estimated to average $\$ 164$ per month for the wage-reliant, about $\$ 22$ for the welfarereliant, and just under $\$ 70$ for the other two groups.

Welfare-based Income. Three categories of welfare-based income are shownTANF cash assistance, food stamps, and income from SSI, Social Security, and

\footnotetext{
${ }^{5}$ We do not subtract housing expenses from gross income in Table 1 because they are not work-related. Our treatment of housing expenses is consistent with the recommendations for measuring the poverty rate of the Panel on Poverty and Family Assistance (Citro and Michael, 1995). The panel proposed that resources should include all sources of cash and near cash income and subtract taxes paid, work-related transportation and child-care expenses, and out-of-pocket medical expenses. We do not have data on out-of-pocket medical expenses. We do not account for the fact that residents of assisted housing will pay higher rents when they move from welfare to work. Only 12 percent of wage-reliant mothers and 19 percent of women combining work and welfare reported living in assisted housing. And, in our sample, mean rents were very similar across all work and welfare categories.
} 
other pension and disability income. Welfare-reliant mothers received TANF benefits that averaged $\$ 365$, combiners, $\$ 195$. In Michigan, in 1999, the maximum cash benefit for a mother with two children was between $\$ 450$ and $\$ 500$, depending upon county of residence. Working recipients can keep the first $\$ 200$ per month without it affecting their benefits; each additional dollar earned beyond this amount reduces welfare benefits by 80 cents. Assuming no income other than earnings, a single mother with two children can earn approximately $\$ 800$ a month before cash benefits end. ${ }^{6}$

Both welfare-reliant mothers and combiners were much more likely to receive food stamps as wage-reliant mothers and women not working or receiving welfare-about 90 percent of those in the former two groups, compared to less than 40 percent in the latter two.

The situation of women in this sample who combine work and welfare in a given month is not atypical. The Urban Institute's 1999 State TANF Income Calculator was used to estimate monthly income for a hypothetical woman earning $\$ 625$ per month (the mean for combiners in Table 1). The estimated total income from earnings, TANF, and food stamps, after adjusting for federal taxes and the federal earned income tax credit ranges from $\$ 1119$ to $\$ 1384$ in the 10 states, including Michigan, that account for 70 percent of the 1999 federal TANF caseload (Allen and Kirby, 2000; Urban Institute, 2000). ${ }^{7}$ In this sample, combiners' average income was in about the middle of this range.

One in six working mothers, about 40 percent of welfare-reliant mothers, and 27 percent of nonworking, nonwelfare mothers reported that they or someone else in the household received SSI, Social Security, or other disability or pension income. The higher incidence of receipt among the welfare-reliant suggests that care-giving responsibilities for disabled household members may deter some respondents from working or allow them to qualify for deferrals from the state's work requirements.

Network-based Income. Two sources of network-based income are reported in Table 1-child support and cash contributions from friends or family. Mothers not receiving welfare were somewhat more likely to receive child support from an absent father than welfare recipients, and the average amount of child support received by nonrecipients was significantly higher. One-quarter of wage-reliant mothers and one-fifth of women who neither worked nor received welfare, compared with about one-sixth of mothers in the two welfare groups, reported receiving child support. The average monthly amounts received by those who received any child support were $\$ 232, \$ 106, \$ 66$, and $\$ 320$, respectively.

About 14 to 19 percent of the groups reported receiving cash contributions from friends and/or family; the average amounts received ranged from $\$ 137$ to 268 per

\footnotetext{
${ }^{6}$ Some women who are classified as combiners reported to us earnings high enough to make them ineligible for TANF. In some cases this may have been due to administrative error and benefits may have been recouped at a later date. However, some women may not have reported these earnings to the welfare agency. Edin and Lein, for example, find that a substantial percentage of their respondents did not report all of their income to the welfare agency. We did not ask respondents if they reported their earnings to the state agency. However, the fact that we have cases where a woman reports substantial earnings and the state reports that she received the TANF benefit for a family of her size with no earnings suggests that some respondents have a higher income as combiners than they would have if they had followed all income reporting requirements.

${ }^{7}$ The other states are California, Florida, Georgia, Illinois, New York, Ohio, Pennsylvania, Texas, and Washington. These states, along with Michigan, contained 53 percent of the overall national population in 1999 (Allen and Kirby, 2000).
} 
month. Just as with child support and the earnings of other household members, welfare-reliant mothers received the smallest amounts on average.

Other Income. A very small percentage of respondents reported income from unemployment insurance, worker's compensation, or other income sources (e.g., insurance settlements). The amounts received are in some cases substantial.

Work-related Transportation and Child Care Expenses. Edin and Lein concluded that higher work-related transportation and child-care costs were one reason wage-reliant mothers experienced more material hardships than welfare-reliant mothers. Also, working women in this study had higher child-care and transportation costs than did welfare-reliant women. The majority of both groups of working mothers-86 percent of the wage-reliant and 67 percent of combiners-reported workrelated transportation expenses that averaged $\$ 91$ and $\$ 71$ per month, respectively.

About one-third of the wage-reliant and one-quarter of the combiners reported out-of-pocket child care expenses that averaged about $\$ 280$ per month. About 10 percent of nonworking mothers also reported work-related child-care expenses, probably because they were searching for work or had recently left a job. The percentages of working mothers who reported child-care expenses were relatively low, in part, because some received a state child care subsidy that covered part or all of their child care costs (10.8 and 24.1 percent of the sample, respectively). Others relied on unpaid care (13.9 percent of the sample), had no children under age 14 (10.8 percent of the sample), or did not report using work-related care (27.3 percent of the sample). In Michigan, child care subsidies are available for all welfare recipients and for working families whose income falls below 85 percent of the state median income. State spending on child care has increased dramatically since 1996.

Net Monthly Income. There is much diversity in the receipt of these various income sources. Income from nine sources was summed, and federal income and payroll taxes and transportation and child-care expenses were subtracted. The mean net monthly income is $\$ 1649$ for wage-reliant mothers, $\$ 1205$ for combiners, $\$ 1014$ for welfare-reliant mothers, and \$1193 for women neither working nor receiving welfare. (As mentioned above, net monthly income excludes the estimated value of the EITC and state tax credits because most women receive them as an annual lump sum and not each month.)

Women who have left welfare for work have significantly higher income than the other three groups; their average net income was about 37 percent higher than that of combiners and 63 percent higher than that of the welfare-reliant. Combiners and women who neither worked nor received welfare had incomes that were about 18 percent greater than those of welfare-reliant mothers, but these differences were not significant.

The poverty rate and the mean income-to-needs ratio for the four groups show a similar pattern. Poverty was calculated by dividing net monthly household income by $1 / 12$ of the 1999 official federal poverty threshold for the respondent's household size. Although workers had lower poverty rates than the welfare reliant, most workers remain poor-49.1 percent of wage-reliant mothers and 77.2 percent of women combining work and welfare. The highest poverty rate, 90.8 percent, was that of welfare-reliant mothers. The mean income-to-needs ratio was also highest for the wagereliant (1.2 times the poverty line) and lowest for the welfare-reliant (0.7 times).

\section{Annual Income}

Data on monthly income tend to overstate the economic status of working respondents because many of them do not work in every month during the year; they also 
tend to understate the economic status of nonworking recipients, because many of them have worked in at least some of the months in the year prior to the interview. For example, about 90 percent of respondents worked in at least one month in the period between waves 2 and 3 (Fall 1998 to Fall 1999), but less than half worked in every month.

To address this issue, annual income in calendar year 1998 was analyzed, and respondents were classified by the work and welfare category that best characterizes their situation during "most" of that year. A respondent was classified into a work or welfare category only if she was in that category for at least 7/12 of the time. ${ }^{8}$ Respondents who do not fall into one of these four groups are classified as "mixers." For example, consider a respondent who received welfare, but did not work, in the first three months of the year, who combined work and welfare in the next two months, and who then left welfare and worked in the last seven months of the year. She would be classified in Table 2 as wage-reliant. However, if she had been welfare-reliant in the first 3 months, combined work and welfare in the next 3 , and been wage-reliant in the following six months, she would be classified as a "mixer," because she did not meet the 7/12 requirement for any single category.

This classification results in a somewhat different distribution of respondents in Table 2-34.0 percent are wage-reliant, 25.0 percent are combiners, 16.6 percent are welfare reliant, 7.4 percent are classified as not working and not receiving welfare, and 16.9 percent are "mixers." The biggest changes relative to the monthly categories of Table 1 are declines in the wage-reliant, increases in combiners, and declines in those not working/not receiving welfare. Nonetheless, the patterns of annual economic status across the group are quite similar-the wage-reliant have much higher net income and a much lower poverty rate than the welfare-reliant.

The first row of Table 2 shows self-reported annual earnings during calendar year 1998. Wage-reliant mothers report the highest earnings, on average, $\$ 10,842$; combiners, \$7001; welfare-reliant mothers, \$1163; women neither working nor receiving welfare, \$2137; and mixers, \$4652. Self-reports of total 1998 household income follow the same pattern, with wage-reliant mothers reporting roughly twice as much total income as welfare-reliant mothers. The one exception to this pattern is that the small number of women who neither work nor receive welfare report total household incomes very similar to those of wage-reliant mothers- $\$ 17,416 .{ }^{9}$

The third row presents mean annual income net of taxes (state and federal income and payroll taxes are subtracted and the EITC and the Michigan renter's credit are added) and work-related transportation and child-care expenses, which are the monthly 1998 values for these expenses multiplied by $12 .{ }^{10}$ Because many wage-reliant women did not work in every month, this annualization of monthly expenses probably understates their total income and overstates that of welfarereliant women. Nonetheless, women who were wage-reliant for most of the year

\footnotetext{
${ }^{8}$ We also considered classifications that required a respondent to have been in a category for $2 / 3$ or $3 / 4$ of the months. The differences in the number of women in each group and differences in income across categories were not very sensitive to the choice of a cutoff.

9 The small number of women in this group were more likely than those in the other groups to either live with another earner or to report SSI or pension or disability income. For example about half of the wage reliant met these criteria compared to about two-thirds of the "neither" group.

${ }^{10}$ Almost every working mother was estimated to have been eligible for the EITC. For wage-reliant mothers, rows 2 and 3 in Table 2 are virtually the same, suggesting that, on average, the EITC and homeowner's credit were just about equal to the sum of federal income and payroll taxes, state income tax and work-related child-care and transportation expenses.
} 


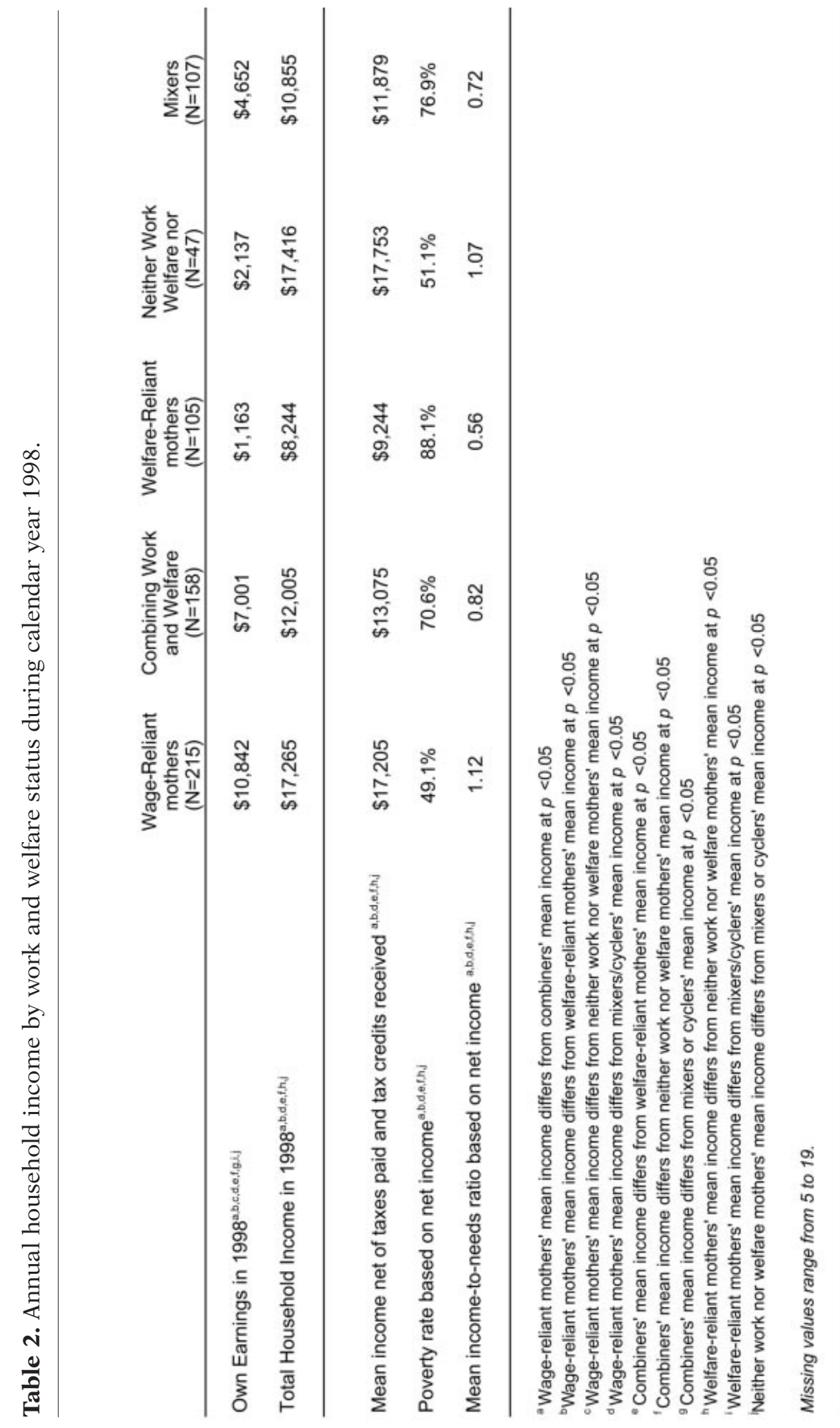


have a net household income 86 percent greater than that of the welfare-reliant; women who combined work and welfare during most of the year have an annual income that is 41 percent higher.

Poverty rates are quite similar in Table 2 to those shown in Table 1 for nearly all groups, and the pattern is consistent despite the annual categorization of work and welfare status rather than the monthly status and the inclusion of the EITC in Table 2 , but not in Table 1. The wage-reliant have much lower poverty rates (49.1 percent) than the welfare-reliant (88.1 percent), with combiners falling in the middle (70.6 percent). The major change between Tables 1 and 2 is the large reduction in the size of the no work/no welfare group, and the increase in their economic well-being. Moving from welfare to combining work and welfare to wage reliance is associated with increased economic well-being. Poverty rates, however, remain high for every group. ${ }^{11}$

\section{Adverse Selection of Nonworkers}

Respondents who have left welfare for work have a higher net income and lower poverty rate than those who remain welfare-reliant. However, some portion of these income differences might be due to differences in the attributes of workers and welfare recipients. Previous research (Danziger, 2001; Danziger et al., 2000) has shown that nonworking respondents have more of the 19 barriers to work measured in Fall 1999 (e.g., physical health problems, mental health problems, low education, and labor force skills) than those who were working. Using the monthly categories of Table 1, for example, wage-reliant women averaged 2.0 barriers, combiners 3.1 barriers, and welfare-reliant mothers 4.7 barriers.

Also, nonworking recipients might have other unmeasured attributes, such as ability or motivation, that lower both their likelihood of employment and their expected earnings if employed. Adverse selection suggests that the benefits of moving from welfare to work are likely to be higher for those who became wage -reliant than for those who remained welfare-reliant. If this is the case, the income gains of moving from welfare to work that are shown in Tables 1 and 2 might be overstated.

To explore the potential effects of adverse selection, fixed-effect regression models were estimated. By controlling for all individual-specific factors that are constant over time, the method eliminates some omitted variable biases (Powers and Xie, 2000). By specifying individual-specific fixed effects, a consistent estimator of the income gains from moving from welfare to work can be derived, provided that the unobserved traits and their effects do not change over time.

As shown in the equation below, each variable is averaged over all time points for a specific woman. This average value is then subtracted from the value at a specific time point for that woman. As a result, the time-invariant measured and unmeasured characteristics of a woman, such as race, drop out of the model.

$$
\begin{aligned}
& \mathrm{Y}_{\mathrm{it}=} \beta^{\prime} \mathrm{X}_{\mathrm{it}}+\gamma \cdot \mathrm{HOURS}_{\mathrm{it}}+\alpha_{\mathrm{i}}+\varepsilon_{\mathrm{it}}, \\
& \Rightarrow\left(\mathrm{Y}_{\mathrm{it}}-\overline{\mathrm{Y}}_{\mathrm{i}}\right)=\beta^{\prime}\left(\mathrm{X}_{\mathrm{it}}-\overline{\mathrm{X}}_{\mathrm{i}}\right)+\gamma\left(\mathrm{HOURS}_{\mathrm{it}}-\overline{\mathrm{HOURS}}_{\mathrm{i}}\right)+\varepsilon_{\mathrm{it}}-\bar{\varepsilon}_{\mathrm{i}}
\end{aligned}
$$

\footnotetext{
${ }^{11}$ When we combine the wage-reliant and the no work and neither work nor welfare groups to get a "leavers" group, the annual 1998 poverty rate was 49.5 percent. This compares with 59 percent in Wisconsin, but we included more income sources than did Cancian et al. (2000).
} 
In this model, $\mathrm{Y}_{\mathrm{it}}$ indicates monthly income net of taxes for individual $i$ in time period $t^{12} \alpha_{i}$ is the individual-specific constant term that accounts for the unobserved time-invariant factors; HOURS it $_{\text {is }}$ the monthly hours that woman $i$ worked on all jobs in year $t ;{ }^{13} \mathrm{X}_{\mathrm{it}}$ and is a vector of individual demographic characteristics and barriers to work. Three observations for each woman are included, Fall 1997, Fall 1998, and Fall 1999. Time-variant characteristics included in the X vector include the number of individuals living in the household, the number of children under age 6 in the household, and a dummy variable indicating if woman $i$ at time $t$ was cohabiting with a husband or partner. Based on work by Danziger et al. (2000) and using variable specifications defined there, dummy variables are also included for five barriers to employment-(1) if the respondent lacked either a car or driver's license; (2) if the respondent met the diagnostic screening criteria for a mental health disorder; (3) if the respondent cared for a child with a physical, learning or mental health problem that limits the child's regular activities; (4) if the respondent had a physical health problem; and (5) if the respondent experienced severe physical partner abuse in the last 12 months.

Also included are interaction terms between time and four time-invariant variables that could affect wage growth: 1) race, a dummy variable indicating if the respondent is an African-American, 2) the number of years the respondent received cash welfare between the time she turned 18 and the Fall 1997 survey; 3) a dummy variable indicating if the respondent had low job skills prior to 1997; and, 4) a dummy variable indicating if the respondent lacked a high school diploma.

Fixed-effect regression results presented in Table 3 show that for every hour a woman works, her monthly net income increases by $\$ 2.63$. The magnitude of this coefficient represents the effect of each additional hour of work net of taxes, and the reduction in food stamps and cash welfare. If it did not pay to move from welfare to work, this coefficient would not be significantly different from zero.

Likewise, if differences in the characteristics of the women themselves, either measured or time-invariant unmeasured characteristics, were the primary determinants of the increased income associated with moving from welfare to work, we would expect to find net income differences largely explained by other factors besides work effort. We do find that living with a spouse or partner and increases in household size are associated with higher monthly income and that an experience of domestic violence is associated with a decrease in income. Of the variables used to examine differential levels of wage growth over time, having less than a high school education is associated with lower monthly incomes in 1999 and years on welfare is associated with a positive, although substantively small, increase in income.

The estimated magnitude of the income gain from work is substantial. Table 1 shows Fall 1999 monthly income differences between the wage reliant and welfare reliant of \$635. In Fall 1999, wage-reliant women worked about 144 hours per month more than the welfare reliant. This differential in hours evaluated at $\$ 2.63$ per hour yields a monthly income difference of $\$ 379$, or about 60 percent of the

\footnotetext{
12 For the purposes of regression analysis, the net monthly income variable does not subtract work-related expenses because such information is not available for calendar year 1997. In addition, the EITC is included in monthly income. The wording for monthly income items changed slightly between waves 2 and 3. For waves 1 and 2, respondents were asked to report categories of income for "you or your husband/partner." In wave 3, respondents were asked to report income for "you or anyone else living here." ${ }^{13}$ Monthly work hours are defined as self-reported hours worked per week multiplied by 4 .
} 
Does It Pay to Move from Welfare to Work? / 685

Table 3. Fixed-effect regression results predicting net monthly income. (Standard Errors in parentheses) $^{\mathrm{a}}$

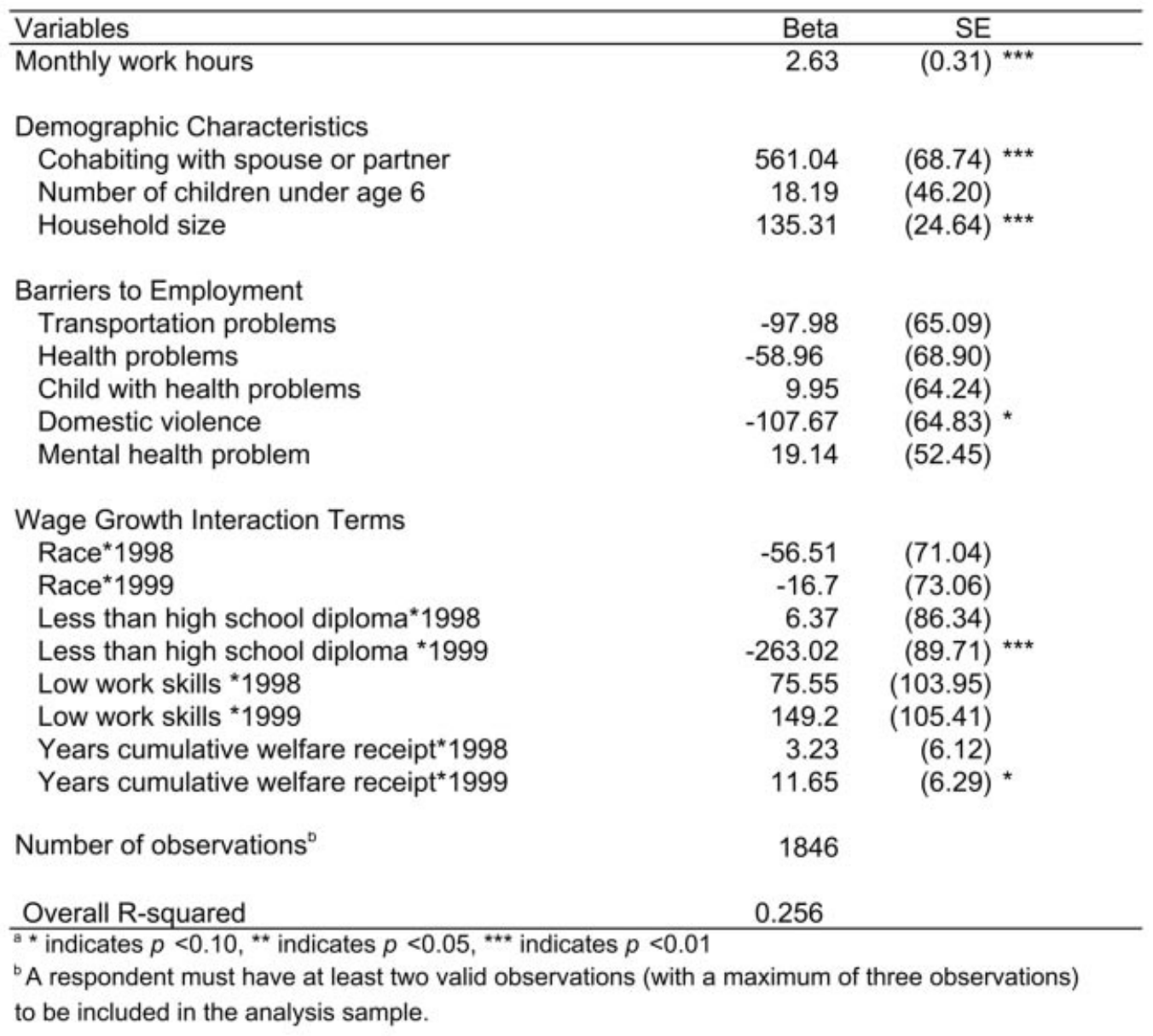

observed monthly income difference between the two groups. Thus, even after controlling for measured and time-invariant unmeasured characteristics, we find that it does pay to move from welfare to work. A number of different model specifications that were estimated yielded similar results. ${ }^{14,15}$

${ }^{14}$ We examined different definitions of income to test for sensitivity in measurement error. In addition to the measure of net monthly income presented in Table 3, we examined net annual income and gross monthly income less other household members' earnings. The coefficient for hours worked in the annual income equation was $\$ 2.17$; in the net monthly income less other household members' earnings model the coefficient on monthly hours of work was $\$ 2.64$.

15 To control for self-selection, we also estimated instrumental variable models, with or without fixed effects, for all three measures of income. We used the district welfare office to which the respondent was assigned as our instrument, since the assignment process is close to random. In contrast to the commonly expected direction of selection bias, we find even greater returns to work in the IV regression results. The details of these analyses are available from the authors on request. 


\section{Experiences of Material Hardship}

Experiences of material hardship were analyzed as was the extent to which mothers engage in activities to make ends meet. ${ }^{16}$ Women who moved from welfare to work were found to be better off in several non-income aspects of economic wellbeing, and worse off only in terms of access to health insurance and having foregone medical and dental care.

Using questions similar to those reported in Mayer and Jencks (1989), and Edin and Lein (1997, p. 113), respondents were asked about 10 types of material hardship. Respondents in Table 4 are classified into work and welfare categories based on what they were doing in 7/12 of the months between waves 2 and $3 .{ }^{17}$ Wage-reliant mothers were significantly less likely to experience three of the material hardships compared to welfare-reliant mothers-having experienced moderate or severe hunger ${ }^{18}$ (12.2 vs. 28.6 percent), having experienced a night of homelessness ( 2.1 vs. 10.0 percent), and having experienced a telephone cutoff ( 25.9 vs. 48.6 percent). They were also less likely to have five or more of eight housing upkeep problems, ${ }^{19}$ to have had utilities cut off and to have been evicted, but these differences were not statistically significant. The extent of hardship for women combining work and welfare tends to fall between those of these two groups for most measures.

The main exceptions to this general pattern were lack of health insurance and having unmet medical and dental needs. ${ }^{20}$ More than one-third of wage-reliant mothers did not have health insurance for themselves, and 13.1 percent did not have insurance for their children. In contrast, almost all welfare-reliant mothers and combiners had medical insurance for themselves and their children. Unmet medical and dental needs were a problem for 41.3 percent of wage-reliant mothers, but only 3.9 percent of their children. ${ }^{21}$ This loss of health insurance in the transition from welfare to work is similar to Edin and Lein's finding that working mothers experience greater hardship than welfare-reliant mothers.

In the bottom part of Table 4 the percentages of women are reported who experienced no hardships, one hardship, or two or more hardships, and the mean num-

\footnotetext{
${ }^{16}$ As mentioned above, our data were gathered during in-home interviews. By the end of the third wave, the typical respondent had spent about 3-1/2 hours with one of our interviewers. Because Edin and Lein spent more time with their respondents, our data on income and expenses may not be as complete as theirs. However, we have little reason to expect that there are differential response biases in the sample across women classified by their work/welfare status.

17 The same classification is used for respondents in Table 5. The median number of months between waves 2 and 3 was 14; it ranged from 8 to 19 months.

${ }^{18}$ Hunger is measured using the Household Food Security scale from the Current Population Survey. Moderate hunger in households with children is defined as 8 to 12 affirmative responses to the 18-item scale; such a score represents a reduction in adults' food intake "to an extent that implies that adults have repeatedly experienced the physical sensation of hunger." Severe hunger is defined as more than 12 affirmative responses, and implies both that children have experienced hunger and that adults "have repeatedly experienced more extensive reductions in food intake.” (Bickel et al., 2000, pp. 12-13).

${ }^{19}$ Respondents were asked if they had experienced these eight housing upkeep problems in the year prior to the interview-leaky roof or ceiling; plumbing problems; rodents or insects; broken windows; broken heating system; electrical problems; lack of stove or refrigerator; inadequate garbage pickup. Those who reported five or more have "severe problems."

20 Respondents were asked, "Was there any time since the wave 2 interview date that you needed to see a doctor or dentist but could not afford to go?"

${ }^{21}$ Medicaid expansions and CHIP now provide coverage for almost all children below 150 percent of the poverty line. Thus, the lack of insurance reported here may indicate a lack of knowledge about eligibility. If these children were brought to an emergency room for treatment, it is likely they would be signed up by the hospital for Medicaid or CHIP. It may also help explain why the percentage of children not receiving needed medical care is so much smaller than it is for their mothers.
} 
Table 4. Experiences of material hardship by work and welfare status between the Fall 1998 and Fall 1999 interviews.

\begin{tabular}{|c|c|c|c|c|c|}
\hline During year previous to Fall 1999 interview & $\begin{array}{l}\text { Wage-Reliant } \\
\text { Mothers } \\
(\mathrm{N}=286)\end{array}$ & $\begin{array}{l}\text { Combining Work } \\
\text { \& Welfare } \\
(\mathrm{N}=93)\end{array}$ & $\begin{array}{l}\text { Welfare-Reliant } \\
\text { Mothers } \\
(\mathrm{N}=70)\end{array}$ & $\begin{array}{l}\text { Neither Work nor } \\
\text { Welfare } \\
(\mathrm{N}=61)\end{array}$ & $\begin{array}{c}\text { Mixers } \\
(\mathrm{N}=122)\end{array}$ \\
\hline No health insurance (mother) ${ }^{0,0,0, a n+4.4}$ & $36.7 \%$ & $5.4 \%$ & $2.9 \%$ & $36.1 \%$ & $15.7 \%$ \\
\hline $\begin{array}{l}\text { Mother did not receive needed medical or } \\
\text { dental care } 20, d, d, j, j\end{array}$ & $41.3 \%$ & $11.8 \%$ & $14.3 \%$ & $37.7 \%$ & $18.9 \%$ \\
\hline No health insurance (child) a,s,a,t,y & $13.1 \%$ & $3.2 \%$ & $0.0 \%$ & $14.8 \%$ & $5.0 \%$ \\
\hline Child did not receive needed medical care & $3.9 \%$ & $5.4 \%$ & $1.4 \%$ & $1.6 \%$ & $2.5 \%$ \\
\hline 5 or more housing upkeep problems & $5.2 \%$ & $10.8 \%$ & $8.6 \%$ & $3.3 \%$ & $5.7 \%$ \\
\hline Telephone cut off ap,n & $25.9 \%$ & $38.7 \%$ & $48.6 \%$ & $27.9 \%$ & $32.2 \%$ \\
\hline \multicolumn{6}{|l|}{ All hardships } \\
\hline No hardships & $31.8 \%$ & $40.2 \%$ & $31.4 \%$ & $34.4 \%$ & $39.5 \%$ \\
\hline One hardship ${ }^{0, n}$ & $22.5 \%$ & $25.0 \%$ & $38.6 \%$ & $21.3 \%$ & $21.8 \%$ \\
\hline Two or more hardships ${ }^{D}$ & $45.7 \%$ & $34.8 \%$ & $30.0 \%$ & $44.3 \%$ & $38.7 \%$ \\
\hline Mean number of hardships & 1.53 & 1.21 & 1.34 & 1.46 & 1.25 \\
\hline \multicolumn{6}{|l|}{ Excluding medical insurance } \\
\hline No hardships & $41.3 \%$ & $40.2 \%$ & $31.4 \%$ & $42.6 \%$ & $43.8 \%$ \\
\hline One hardship ' & $29.7 \%$ & $27.2 \%$ & $40.0 \%$ & $31.1 \%$ & $24.0 \%$ \\
\hline Two or more hardships & $29.0 \%$ & $32.6 \%$ & $28.6 \%$ & $26.2 \%$ & $32.2 \%$ \\
\hline
\end{tabular}

NOTE: Hardships are measured over the 12 months prior to the Fall 1999 interview. Missing values range from 0 to 5 on individual items.

'Wage-reliant mothers' rate differs from combiners' rate at $p<0.05$

'Wage-reliant mothers' rate differs from welfare-reliant mothers' rate at $p<0.05$

' Wage-reliant mothers' rate differs from no work or welfare mothers' rate at $p<0.05$

'Wage-reliant mothers' rate differs from mixers or cyclers' rate at $\rho<0.05$

"Combiners' rate differs from welfare-reliant mothers' rate at $p<0.05$

'Combiners' rate differs from no work or welfare mothers' rate at $\rho<0.05$

' Combiners' rate differs from mixers/cyclers' rate at $p<0.05$

'Welfare-reliant mothers' rate differs from no work or welfare mothers' rate at $p<0.05$

'Welfare-reliant mothers' rate differs from mixers/cyclers' rate at $\rho<0.05$

'No work or welfare mothers' rate differs from mixers or cyclers' rate at $p<0.05$

ber of hardships-first including all 10 hardships, and then excluding two medical insurance questions. There are no significant differences across the five groups, although the wage-reliant are more likely to have no hardships than the welfare reliant when medical insurance is excluded (41.3 vs. 31.4 percent), and have a lower mean number (1.03 vs 1.31). The loss of Medicaid by women who leave welfare for work and who either do not work for an employer who provides health insurance or cannot afford required premiums is a serious problem that was not addressed by the 1996 welfare reform.

\section{Activities to Make Ends Meet}

Respondents were questioned about activities they might have pursued to make ends meet and to raise their material well-being, including informal or irregular work-related activities, such as selling food stamps or seeking charity. Edin and Lein note that "taking a job made the pursuit of work-based strategies more difficult, so that mothers that relied upon these strategies would realize a net loss when they went to work" (1996, p. 263). 


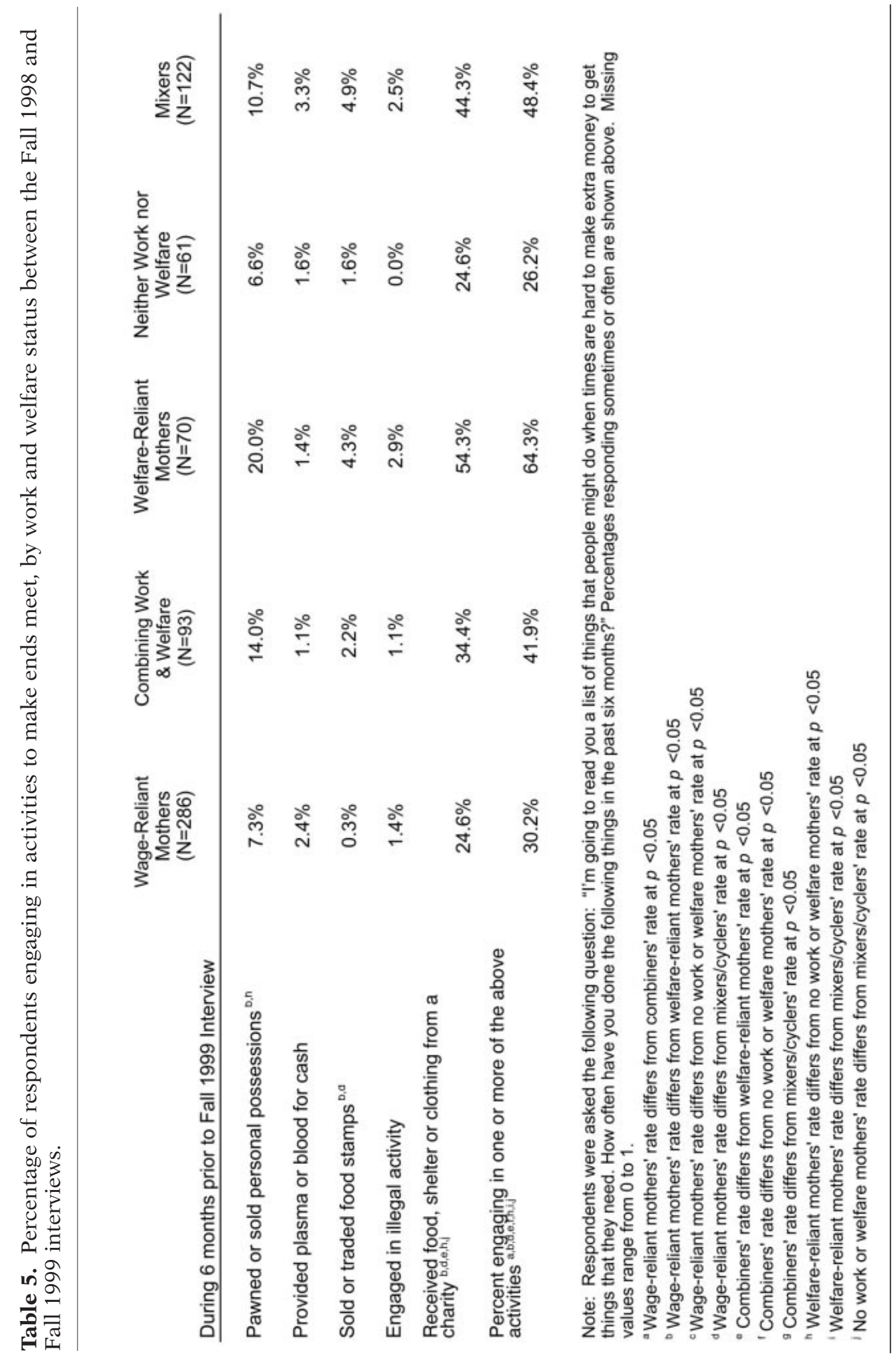


Table 5 shows the proportion of women, classified by their work and welfare category in most of the months between the Fall 1998 and 1999 interviews, who reported engaging in each of the listed activities during the six months before the Fall 1999 interview (receipt of charity is measured over the entire period between waves). Welfare-reliant mothers were significantly more likely than wage-reliant mothers to have pawned or sold personal possessions for cash (20.0 vs. 7.3 percent), sold or traded food stamps ( 4.3 vs. 0.3 percent), and received food, shelter or clothing from a charity (54.3 vs. 24.6 percent). About two-thirds of welfare-reliant mothers engaged in at least one hardship-mediating activity, compared to about two-fifths of combiners and one-third of the wage reliant. Women who neither worked nor received welfare resembled the wage reliant and mixers resembled combiners.

Although these results are consistent with those of Edin and Lein, the interpretation reported here differs. They suggest that wage reliant mothers had less time to pursue these alternative strategies and were thus disadvantaged by working. The results here suggest that working mothers were less likely to pursue these strategies because their net income was higher and poverty rate was lower, and hence they had less need to pursue activities, such as pawning possessions, selling food stamps, or seeking charity, all of which carry social stigma or legal risk.

\section{Subjective Well-being}

Finally, respondents' subjective assessments of their material well-being were examined. Table 6 reports the distributions of responses to the question: "How difficult is it for you to live on your income right now?" Because this question is based on the respondents' situation at the time of the interview, the Fall 1999 monthly work and welfare classification was used.

If Edin and Lein's conclusion about the economic disadvantages of moving from welfare reliance to wage reliance remained true post-welfare reform, wage-reliant mothers should, on average, have reported more difficulty living on their household income. The results in Table 6 are the opposite: 53.5 percent of wage-reliant mothers answered that it was "not at all difficult" or "a little difficult" compared to 35.6 percent of welfare-reliant mothers. Only 9.5 percent of wage-reliant mothers and 13.2 percent of combiners said that it was "extremely difficult," compared with 28.7 percent of the welfare-reliant. According to their own subjective evaluations, working mothers reported less difficulty making ends meet than did welfarereliant mothers.

\section{CONCLUSION}

When Edin and Lein (1997) compared the material well-being of wage-reliant and welfare-reliant single mothers in the late 1980s and early 1990s, they concluded that it usually "did not pay" for welfare mothers to take a job. More recent research (Bavier, 2000; Cancian et al., 2000) found modest financial gains among welfare recipients who became wage-reliant after welfare reform. This issue was revisited using Fall 1999 panel data; those who had moved from welfare to work were found, objectively and subjectively, to be better off financially than those who remained welfare reliant. Working mothers had higher household incomes, lower poverty rates, experienced a similar level of material hardships, were less likely to engage in activities to make ends meet, and reported less difficulty living on their current incomes. 
Table 6. Subjective financial strain by work and welfare status in Fall 1999.

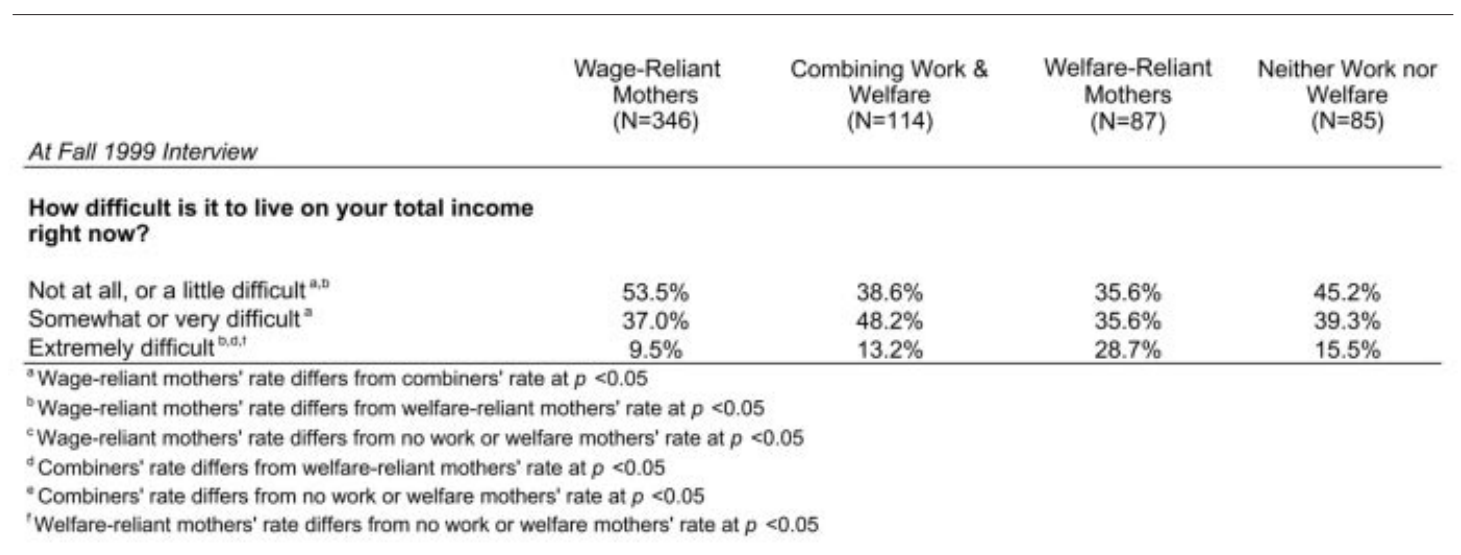

Several factors contributed to these differences in well-being. First, some combination of a tighter labor market, a higher minimum wage, the increased EITC, increased medical insurance for children, and increased subsidies for child care made work pay more relative to cash assistance in the late 1990s than at the beginning of the decade. Second, a substantial portion of our respondents combined welfare and work. This reflects a recent policy shift, as many states increased the amount of earned income that is disregarded in the computation of welfare benefits. Women whose earnings would have disqualified them from cash assistance a decade ago can now receive some welfare benefits and maintain Medicaid for themselves and their children.

Results reported here are consistent with those of Edin and Lein and others in several respects. First, they confirm that many working mothers could not make ends meet on their paychecks alone; they continue to receive government assistance (e.g., TANF, food stamps, EITC) or to rely upon cash contributions from friends and family. Second, poverty remains high, even among the wage reliant; about half of the wage-reliant mothers reported experiencing at least two material hardships during the previous year; and about one-quarter of the wage reliant and one-third of combiners reported receiving food, shelter or clothing from a charity.

The policies now in place have changed economic incentives so that they are in accord with the goals of PRWORA-i.e., on average, wage-reliant mothers and those combining work and welfare are financially better off than welfare-reliant mothers. Yet, insufficient policy attention has been paid to factors that may have prevented those who remained welfare reliant about three years after the Act's implementation from making the transition to work. The new economic incentives and the increased pressure to leave the welfare rolls suggest that few welfare-reliant mothers are able to reject work and choose to stay on welfare. It seems more likely that many of them have problems, such as poor physical or mental health or lack of job skills, which prevent them from getting jobs even when unemployment rates are low (Danziger, 2001; Danziger et al., 2000).

Even though it now pays to move from welfare reliance to wage reliance, there remains a need for additional policy enhancements to make work pay enough so that a greater percentage of working mothers can escape poverty and afford medical insurance, as well as a need for enhanced policies to help welfare-reliant mothers move into regular jobs or into subsidized employment. 
This research was supported in part by grants from the Charles Stewart Mott Foundation, the Joyce Foundation, the John D. and Catherine T. MacArthur Foundation, and the National Institute of Mental Health (R24-MH51363). Gregory Acs, Nath Anderson, Rebecca Blank, Irwin Garfinkel, Harry Holzer, Harold Pollack, Robert Schoeni, Wendell Primus, Kristin Seefeldt, Eugene Smolensky, Jane Waldfogel, and several anonymous referees provided helpful comments on previous drafts.

SHELDON DANZIGER is Henry J. Meyer Collegiate Professor of Social Work and Public Policy at the Gerald R. Ford School, University of Michigan.

COLLEEN M. HEFLIN is Assistant Professor of Public Policy at the University of Kentucky.

MARY E. CORCORAN is Professor of Public Policy, Political Science, and Social Work, at the University of Michigan.

ELIZABETH OLTMANS is a graduate student in Economics at the Massachusetts Institute of Technology.

HUI-CHEN WANG is a graduate student in Economics at the University of Michigan.

\section{REFERENCES}

Acs, G., Coe, N., Watson, K., \& Lerman, R. (1998). Does work pay? An analysis of the work incentives under TANF. Washington, DC: Urban Institute.

Allen, K., \& Kirby, M. (2000). Unfinished business: why cities matter to welfare reform. Washington, DC: Brookings Institution.

Bauman, K. (2000). The Effect of work and welfare on living condition in single parent households, Working Paper no. 46. Washington, DC: U.S. Census Bureau. Available at: www.census.gov/population/www/documentation/twps0046.pdf. Accessed May 24, 2002.

Bavier, R. (2001a). Welfare reform data from the Survey of Income and Program Participation. Monthly Labor Review 124(7), 13-24.

Bavier, R. (2001b). A look at welfare reform in the survey of income and program participation. Unpublished manuscript. Washington, DC: Office of Management and Budget.

Beverly, S. (2000). Material hardship in working-poor households with children: evidence from the survey of income and program participation. Unpublished manuscript, Washington University.

Bickel, G., Nord, M., Price, C., Hamilton, W., \& John Cook, J. (2000). Guide to measuring household food security. U.S. Department of Agriculture. Available at: http://www.fns.usda.gov/fsec/FILES/FSGuide.pdf. Accessed May 24, 2002.

Blank, R. (1997). It takes a nation: a new agenda for fighting poverty. Princeton, NJ: Princeton University Press.

Broaddus, M., Blaney, S., Dude, A., Guver, J., Ku, L., \& Peterson, J. (2002). Expanding family coverage: state's Medicaid eligibility policies for working families in the year 2000. Washington, DC: Center for Budget and Policy Priorities. Available at: http://www.cbpp.org/1-2-02health.pdf. Accessed May 24, 2002.

Cancian, M., Haveman, R., Meyer, D., \& Wolfe, B. (2000). Before and after TANF: the economic well-being of women leaving welfare, Special Report \#77. Madison, WI: Institute for Research on Poverty.

Cancian, M., Haveman, R., Meyer, D., \& Wolfe, B. (2002). Before and after TANF: the economic well-being of women leaving welfare, Discussion Paper no 1244-02. Madison, WI: Institute for Research on Poverty.

Citro, C.F., \& Michael, R.T. (Eds.). (1995). Measuring poverty: a new approach. Washington, DC: National Academy Press. 
Danziger, S. (Ed.) (1999). Economic conditions and welfare reform. Kalamazoo, MI: Upjohn Institute for Employment Research.

Danziger, S. (2001). Comment: TANF and the most disadvantaged families' well-being. In Blank and Haskins (Eds.), The new world of welfare (pp. 410-415). Washington, DC: Brookings Institution.

Danziger, S.K., Corcoran, M., Danziger, S., Heflin, C., Kalil, A., Levine, J., Rosen, D., Seefeldt, K., Siefert, K., \& Tolman, R. (2000). Barriers to the employment of welfare recipients. In Cherry \& Rodgers (Eds.), Prosperity for all? (pp. 239-277). New York: Russell Sage Foundation.

Edin, K., \& Lein, L. (1996). Work, welfare, and single mother's economic survival strategies. American Sociological Review, 61, 253-266.

Edin, K., \& Lein, L. (1997). Making ends meet: how single mothers survive welfare and lowwage work. New York: Russell Sage Foundation.

Ellwood, D. (2000). Anti-poverty policy for families in the next century: from welfare to work-and worries. Journal of Economic Perspectives, 14(1), 187-198.

Feenberg, D, \& Coutts, E. (1993). An introduction to the TAXSIM model. Journal of Policy Analysis and Management, 12(1), 189-194.

Gallagher, L. J., Gallagher, M., Perese, K., Schreiber, S., \& Watson, K. (1998). One year after welfare reform: a description of state temporary assistance for needy families (TANF) decisions as of October 1997. Washington, DC: Urban Institute. Available at: http://www.urban.org/UploadedPDF/307472_Tanf2.pdf. Accessed May 24, 2002.

Holzer, H.J., \& Stoll, M.A. (2001). Employers and welfare recipients: the effects of welfare reform in the workplace. San Francisco: Public Policy Institute of California.

Mayer, S.E., \& Jencks, C. (1989). Poverty and the distribution of material hardship. Journal of Human Resources, 24, 88-113.

Meyer, B., \& Rosenbaum, D. (2000). Making single mothers work: recent tax and welfare policy and its effects. National Tax Journal, 53, 1027-1061.

National Bureau of Economic Research. (2002). The TAXSIM model. Available at: http://www.nber.org/ taxsim. Accessed May 24, 2002.

Pavetti, L.D. (2002). Welfare policy in transition: redefining the social contract for poor citizen families with children and immigrants. In Danziger \& Haveman (Eds.), Understanding poverty (pp. 229-277). Cambridge, MA: Harvard University Press.

Powers, D.A., \& Xie, Y. (2000). Statistical methods for categorical data analysis. New York: Academic Press.

State of Michigan. (2000). Family Independence Agency, Temporary Assistance for Needy Families State Plan (10/1/98-9/30/2000).

Urban Institute. (2000). State TANF income calculator. Available at: http://newfederalism.urban.org/incalc2/index.html. Accessed May 24, 2002.

Wolfe, B. (2002). Incentives, challenges and dilemmas of TANF design: a case study. Journal of Policy Analysis and Management 21(4), 577-586. 